[Article]

\title{
水溶液中银阴极对 $3,4,5,6$-四氯吡啶甲酸脱氯反应的催化作用
}

\author{
马红星 葛婷婕 蔡倩倩 徐颖华 ${ }^{*}$ 马淳安 ${ }^{*}$ \\ (浙江工业大学化学工程学院, 绿色化学合成技术国家重点实验室培养基地, 杭州 310032)
}

\begin{abstract}
摘要: 粗糙银 $(\mathrm{Ag}(\mathrm{r}))$ 电极对水溶液中 $3,4,5,6$-四氯吡啶甲酸 $(\mathrm{TeCP})$ 脱氯反应具有非凡的催化作用, 这与非质 子溶剂中氯代有机物的电化学还原的报导结论截然相反。为充分认识水溶液中银电极对 $3,4,5,6$-四氯吡啶甲 酸的电化学还原反应非凡的催化作用, 我们基于表面分析、原位电化学研究和理论计算这三点进行了综合研 究。本文首先采用透射电子显微镜(TEM)和X射线光电子能谱(XPS)观察了粗糙银的表面结构和化学状态。 实验结果表明, 氧化还原循环过程中, 电极表面会形成银纳米粒子, 从而导致表面无序程度的增加。我们还 分别做了针对第一个电子转移过程的密度泛函理论(DFT)计算、电化学原位表面增强拉曼光谱(SERS)研究以 及加入 $\mathrm{H}^{+}$的循环伏安法 $(C V)$ 实验来表征不同电位区间电极表面的物质变化。实验结果表明银可以催化 TeCP 脱氯的第一个电子转移步骤。这是因为其自由基中间产物( $\left(\mathrm{TeCP}{ }^{-}\right.$) 可以比 $\mathrm{TeCP}$ 更强烈地吸附在 $\mathrm{Ag}(\mathrm{r})$ 电极表 面。脱氯反应的关键中间体 $\mathrm{TeCP}$ - 的存在表明 $\mathrm{TeCP}$ 在银电极上的反应路径不同于在玻碳( $\mathrm{GC}$ )电极的外层 电子转移还原。
\end{abstract}

关键词: 3,4,5,6-四氯吡啶甲酸; 表面增强拉曼光谱; 密度泛函理论; 银电极; 电催化机理; 脱氯; 吸附 中图分类号: 0646

\section{Catalytic Effect of Silver Cathodes on 3,4,5,6-Tetrachloropicolinic Acid Dechlorination in Aqueous Solutions}

\author{
MA Hong-Xing GE Ting-Jie CAI Qian-Qian XU Ying-Hua* MA Chun-An* \\ (State Key Laboratory Breeding Base of Green Chemistry-Synthesis Technology, College of Chemical Engineering, \\ Zhejiang University of Technology, Hangzhou 310032, P. R. China)
}

\begin{abstract}
Dechlorination of 3,4,5,6-tetrachloropicolinic acid (TeCP) on roughened silver $(\mathrm{Ag}(\mathrm{r}))$ cathodes provides an unexpected example showing extraordinary catalytic effect in aqueous solution, which is counter to what has been reported in electrochemical reduction of organic halides using aprotic media. To fully recognize this extraordinary catalytic effect of silver cathodes on electrochemical reduction of 3,4,5,6-tetrachloropicolinic acid in aqueous solutions, we conduct a comprehensive study from the aspect of surface characterization, in situ electrochemical study, and theoretical calculation. Transmission electron microscopy (TEM) images and X-ray photoelectron spectroscopy (XPS) spectra are presented to observe the surface structure and chemical state of $\mathrm{Ag}(\mathrm{r})$. Experimental results show that Ag nanoparticle can be formed in the oxidation-reduction cyclic (ORC) process, which leads to an increase in the degree of surface disorder. Density functional theory (DFT) calculations of the first electron transfer (ET) process, integrated with an in situ electrochemical surfaceenhanced Raman spectroscopy (SERS) study and a cyclic voltammetry (CV) experiment with the aid of $\mathrm{H}^{+}$, were performed to characterize various surface species in different electrode potential regions. Experimental evidence shows that the first $\mathrm{ET}$ process is catalyzed by silver for the radical derivate $\left(\mathrm{TeCP}^{{ }^{-}}\right)$formed by the ET process
\end{abstract}

Received: March 2, 2016; Revised: April 12, 2016; Published on Web: April 12, 2016.

*Corresponding authors. XU Ying-Hua, Email: xuyh@zjut.edu.cn. MA Chun-An, Email: science@zjut.edu.cn; Tel/Fax: +86-571-88320813. The project was supported by the National Natural Science Foundation of China (21106133, 21576238), Natural Science Foundation of Zhejiang Province, China (LY16B060012), and National Key Basic Research Program of China (973) (2012CB722604).

国家自然科学基金(21106133, 21576238), 浙江省自然科学基金(LY16B060012)及国家重点基础研究发展规划项目(973) (2012CB722604)资助

(C) Editorial office of Acta Physico-Chimica Sinica 
is adsorbed more strongly than TeCP. $\mathrm{TeCP}_{\mathrm{ads}}^{--}$is the key intermediate of the dechlorination process, implying that the dechlorination mechanism could drastically differ from the outer-sphere reduction at the glass carbon (GC) electrode.

Key Words: 3,4,5,6-tetrachloropicolinic acid; Surface-enhanced Raman spectroscopy; Density functional theory; Silver electrode; Electrocatalytic mechanism; Dechlorination; Adsorption

\section{Introduction}

Electrochemical reductive dehalogenation of organic halides is one of the most important reactions in organic electrochemisty, it possesses important application value both for organic synthesis ${ }^{1}$ and for environmental protection ${ }^{2-4}$. Recently, Ag has attracted much attention as a catalytic cathode material from mechanistic viewpoint $^{5-8}$, due to its extraordinary electrocatalytic properties towards the reduction process.

There are two possible mechanisms for the electrochemical reductive cleavage of carbon-halogen bonds in organic compounds at inert electrodes such as glassy carbon'. Electron transfer (ET) and bond breaking can occur either in stepwise manner with the intermediate formation of a radical anion (Eqs.(1), (2)) or in a concerted way yielding a radical and a halide ion directly (Eq.(3)).

$$
\begin{aligned}
& \mathrm{RX}+\mathrm{e}^{-} \rightleftharpoons \mathrm{RX}^{\bullet-} \\
& \mathrm{RX}^{\bullet-} \rightarrow \mathrm{R}^{\bullet}+\mathrm{X}^{-} \\
& \mathrm{RX}+\mathrm{e}^{-} \rightarrow \mathrm{R}^{\bullet}+\mathrm{X}^{-}
\end{aligned}
$$

The relationship between electrocatalysis and the mechanism of dissociative ET at Ag cathode has been extensively investigated $^{10-12}$. It has been shown that reduction of alkyl halides follows a concerted mechanism, whereas ET to an aromatic halide gives transient radical anions. Electrocatalysis is strictly related to the concerted nature of the dissociative ET to the carbon-chlorine bond. Most reported aryl chlorides generally undergo stepwise reductive cleavage and do not show any catalytic effect. In addition, it is found that the surface morphology of Ag cathode has only a very modest effect on the electrocatalytic reduction of various organic halides ${ }^{13-15}$. These mentioned above presents acknowledged rules in electrochemical dechlorination over Ag using aprotic media.

For voltammetric data alone, could not help unravel the exact mechanistic origin of this kind of strong catalysis, GonzalezGarcia group carried out an in situ electrochemical surface-enhanced Raman spectroscopy (SERS) study on the reductive dechlorination of perchloroethylene ${ }^{16}$ and trichloroacetic $\operatorname{acid}^{17}$, aiming to obtain detailed molecular-level information of the process. Considering the fact that the assignment of some acquired surface-enhanced Raman bands is very difficult, perhaps, Tian group $^{18,19}$ chose a method of SERS coupled with density functional theory (DFT) calculations to investigate the mechanism of benzyl chloride reduction.

This work describes the results of electroreduction of 3,4,5,6tetrachloropicolinic acid $(\mathrm{TeCP})$ at a roughened silver cathode, in which an unexpected example showing important catalytic effect in the reduction of aromatic chlorides will be presented. Because
TeCP and its reductive product are derivatives of the SERS prototype molecule pyridine ${ }^{20}$ and pyridine carboxylic acids ${ }^{21,22}$, the acquired surface-enhanced Raman bands can be assigned conveniently. So, in situ electrochemical SERS study could provide crucial clues to indentify the existence of intermediate formed through dechlorination process. Therefore, a precise description of the dechlorination mechanism of silver cathode with remarkable electrocatalytic properties can be made by the integration of voltammetry, DFT calculation, and SERS analysis data.

\section{Experimental}

\subsection{Chemicals}

TeCP, 3,5,6-trichloropicolinic acid (3,5,6-T), 3,6-dichloropicolinic acid (3,6-D), and 3,5-dichloropicolinic acid (3,5-D) with a purity of $98 \%-99 \%$ were obtained from Zhejiang Avilive Chemical Co., Ltd., China (www.avilive.com), and used as received. $\mathrm{NaOH}, \mathrm{NaClO}_{4}, \mathrm{HClO}_{4}$, and $\mathrm{NaCl}$, with $97 \%-99 \%$ purity, were obtained from the Aladdin Reagent Co., China, and used as received. Acetonitrile and methanol (HPLC-grade) were purchased from the National Medicines Co. Ltd., China. All solutions were prepared using $\mathrm{H}_{2} \mathrm{O}$ with a resistivity of $18.2 \mathrm{M} \Omega \cdot \mathrm{cm}$ obtained from a Millipore Milli-Q system.

\subsection{Electrodes preparation and characterization}

Two types of Ag electrodes namely $\mathrm{Ag}(\mathrm{p})$ and $\mathrm{Ag}(\mathrm{r})$ were used. $\operatorname{Ag}(\mathrm{p})$ was made by polishing the bulk metal with $0.3-\mu \mathrm{m}$ alumina powder, whereas $\mathrm{Ag}(\mathrm{r})$ was prepared in $0.5 \mathrm{~mol} \cdot \mathrm{L}^{-1} \mathrm{NaCl}$ aqueous solution by an oxidation-reduction cyclic process ${ }^{23-25}$ at a scan rate of $10 \mathrm{mV} \cdot \mathrm{s}^{-1}$ and in the range of -0.4 to $0.4 \mathrm{~V}, 4$ cycles.

X-ray photoelectron spectroscopy (XPS, KRATOS AXIS ULTRA DLD) with a monochromatized aluminium X-ray source was used to confirm the chemical states of Ag. For the spectra deconvolutions, an XPS analysis program XPS Peak 4.1 was used, and a Lorentz-gauss algorithm was applied. The binding energies were calculated with $\mathrm{C} 1 s$ peak $(284.8 \mathrm{eV})$ as internal standard. Transmission electron microscopy (TEM) images were recorded by the transmission electron microscope (FEI, Tecnai G2 F20). Silver particles from oxidation-reduction cyclic (ORC) process of $\mathrm{Ag}$ electrode were first ground in an agate mortar with methanol and then dispersed in an ultrasonic bath.

\subsection{Cyclic voltammetry experiments}

Cyclic voltammetry (CV) investigations and preparative were carried out by a PAR 273A potentiostat. A three-electrode cell composed of an $\mathrm{Ag} / \mathrm{AgCl} / \mathrm{KCl}$ (saturated in water), a $\mathrm{Pt}(2 \mathrm{~cm} \times$ $2 \mathrm{~cm}$ ) counter electrode, and GC, Ag working electrode $(\phi 2 \mathrm{~mm})$ was used for voltammetric investigations. 


\subsection{Preparative electrolysis experiments}

Preparative electrolyses were carried out in a conventional two compartment glass H-cell, separated by a Nafion-117 membrane. The volume of catholyte and anolyte were both $30 \mathrm{~mL}$, with catholyte stirred by Teflon coated magnetic stirring bar during the electrolysis process. Platinum sheet $(2 \mathrm{~cm} \times 3 \mathrm{~cm})$ and $\mathrm{Ag}(\mathrm{r})$ electrode $(3.0 \mathrm{~cm} \times 2.5 \mathrm{~cm}$ mesh $)$ in aqueous solutions with different $\mathrm{pH}$ values were used as anode and cathode, respectively. Quantitative analysis of the dechlorinated products and the remaining reactant was performed at room temperature by using a Waters HPLC system with a symmetry column $(250 \mathrm{~mm}$ length $x$ $4.6 \mathrm{~mm}$ i.d., $5 \mu \mathrm{m}$ particle size), an injection valve fitted with 20 $\mu \mathrm{L}$ sample loop, and a Waters 2996 Photodiode Array Detector $(\lambda$ $275 \mathrm{~nm}$ ). Isocratic elution was used with a mobile phase of acetonitrile/methanol/ $\mathrm{H}_{2} \mathrm{O}(1: 3: 6, V / V)$ containing $30 \mathrm{mmol} \cdot \mathrm{L}^{-1}$ $\mathrm{H}_{3} \mathrm{PO}_{4}$ at a flow rate of $1 \mathrm{~mL} \cdot \mathrm{min}^{-1}$. The quantitative calculation was carried out by external standard method. The yield was determined as the molar ratio of dechlorinated product produced to the initial amount of TeCP. All electrolysis experiments were performed at $25{ }^{\circ} \mathrm{C}$ and ambient pressure. All the potentials reported were relative to $\mathrm{Ag} / \mathrm{AgCl} / \mathrm{KCl}$ (saturated in water).

\subsection{Raman spectra and DFT calculation}

Raman spectra were obtained with a LabRam inVia Raman Microscope (from Renishaw) and $300 \mathrm{~nm}$ pinhole was employed. The excitation wavelength was $785 \mathrm{~nm}$ and the acquisition time was $10 \mathrm{~s}$. DFT calculation was used with the hybrid exchange functional of $\mathrm{B}^{2} \mathrm{LYP}^{26}$. Silver clusters of $\mathrm{Ag}_{4}$ were used to simulate $\mathrm{Ag}$ electrode interface and were described by the basis set of LanL2DZ. For C, N, O, Cl, and H, the basis sets ${ }^{27,28}$ were $6-311+$ $\mathrm{G}(d, p)$. Gaussian 03 software package ${ }^{29}$ was used to perform all the calculations and simulations.

\section{Results and discussion}

\subsection{Catalytic reduction of $\mathrm{TeCP}$ over $\mathrm{Ag}(\mathrm{r})$ electrode and its characterization}

\subsubsection{Catalytic reduction of TeCP over $\mathrm{Ag}(\mathrm{r})$ electrode}

The electrochemical properties of electrodes with different surface morphology ${ }^{23,24}$ were investigated by cyclic voltammetry. Fig. 1 presents the $\mathrm{CV}$ curves recorded on $\mathrm{Ag}(\mathrm{p}), \mathrm{Ag}(\mathrm{r})$, and GC electrodes for the reduction of TeCP in $0.5 \mathrm{~mol} \cdot \mathrm{L}^{-1} \mathrm{NaClO}_{4}$ aqueous solution. The shape of the $\mathrm{CV}$ curves strongly depends on the material of working electrode and difference in cathodic peak associated to the reduction of $\mathrm{TeCP}$ can be clearly observed when electrodes with different morphologies were used. GC electrode has been previously shown to be the best approximation of an outer-sphere electron donor for the reduction of organic halides, so the positive shifts observed at $\mathrm{Ag}$ can be attributed to the electrocatalytic properties of such a cathode ${ }^{6,8}$. An obvious positive shift (approximately $0.20 \mathrm{~V}$ ) of the onset reduction potential for the reduction of $\mathrm{TeCP}$ is observed at an $\mathrm{Ag}(\mathrm{p})$ electrode (Fig.1) which confirms that the reduction process is catalyzed by the $\operatorname{Ag}(\mathrm{p})$ electrode. In addition, the onset reduction potential of TeCP become even more positive and the reductive current be-

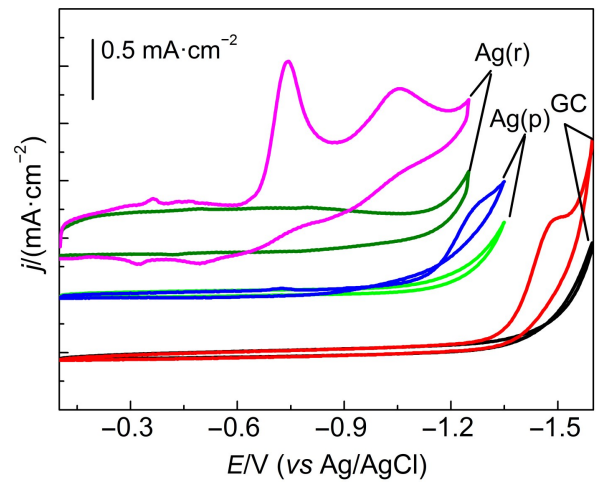

Fig.1 Cyclic voltammograms of three electrodes in absence/ presence of $5 \mathrm{mmol} \cdot \mathrm{L}^{-1} \mathrm{TeCP}$

supporting electrolyte: $0.5 \mathrm{~mol} \cdot \mathrm{L}^{-1} \mathrm{NaClO}_{4}, \mathrm{pH}=7.0$, scan rate $(v)=50 \mathrm{mV} \cdot \mathrm{s}^{-1}$

come considerable higher at the $\mathrm{Ag}(\mathrm{r})$ electrode compared with the $\operatorname{Ag}(\mathrm{p})$ electrode.

Apparently, the $\operatorname{Ag}(\mathrm{r})$ electrode has higher surface area ${ }^{23,24}$, which is desirable for a higher cathodic peak current. However, the potential where dechlorination occurs cannot be moved only by the variation of surface area. Hence the observed raise of the current and especially the shift of reduction potential are obviously due to the improvement of electrocatalytic activity of an $\mathrm{Ag}(\mathrm{r})$ electrode besides the increase of surface area. These two results are indisputable opposed to what has been previously reported in aprotic media that $\mathrm{Ag}$ does not show any catalytic effects for all aromatic chlorides ${ }^{10-12}$ and surface roughness has only a modest effect on the electrocatalytic ability of $\mathrm{Ag}^{13-15}$. In fact, we have previously reported several special cases in the reduction of chlororganics ${ }^{23-25}$ which are also contrary to the two rules above. Unfortunately, it was not possible to explain such a discrepancy on the basis of the data available at that time.

\subsubsection{Surface morphology of $\mathrm{Ag}(\mathrm{r})$ electrode}

To interpret such extraordinary electrocatalytic property of $\mathrm{Ag}(\mathrm{r})$, XPS survey spectra and typical XPS scan of $\mathrm{Ag} 3 d$ region are shown in Fig.2(a, b). Peaks at 532.0 and $284.8 \mathrm{eV}$ corresponding to $\mathrm{O} 1 s$ and $\mathrm{C} 1 s$ can be seen clearly at XPS survey spectra, indicating the existence of oxide on $\mathrm{Ag}(\mathrm{r})$ electrode. Noting that $\mathrm{Cl} 2 s(270.2 \mathrm{eV}), \mathrm{Cl} 2 p(199.1 \mathrm{eV}), \mathrm{Na} 1 s(1070.0 \mathrm{eV})$, and $\mathrm{Na} K L L(496.8 \mathrm{eV})$ peaks can also be observed due to the ORC process at $\mathrm{NaCl}$ aqueous solution. The $\mathrm{Ag} 3 d_{5 / 2}$ and $3 d_{3 / 2}$ appear at $374.4 \mathrm{eV}$ and $368.4 \mathrm{eV}$ in Fig.2(b) and it was worthwhile to note that the binding energy shifts to higher value compared to those tested for bulk Ag. It has been established that particle size of Ag can influence core level shifts significantly and specifically, Ag particle size below $10 \mathrm{~nm}$ resulted core level binding energy shift higher ${ }^{30}$. This conclusion appears to be satisfied with our case and thus strongly suggested the formation of $\mathrm{Ag}$ nanoparticles in the process of ORC.

Quasi-semispherical shape bumps can be clearly recorded with a diameter of about $10 \mathrm{~nm}$ at TEM graph of Ag(r) electrode (Fig.2 (c)) which is consistent with XPS Ag $3 d$ result. Evidence has been provided that Ag nanoparticle presents a better performance to- 

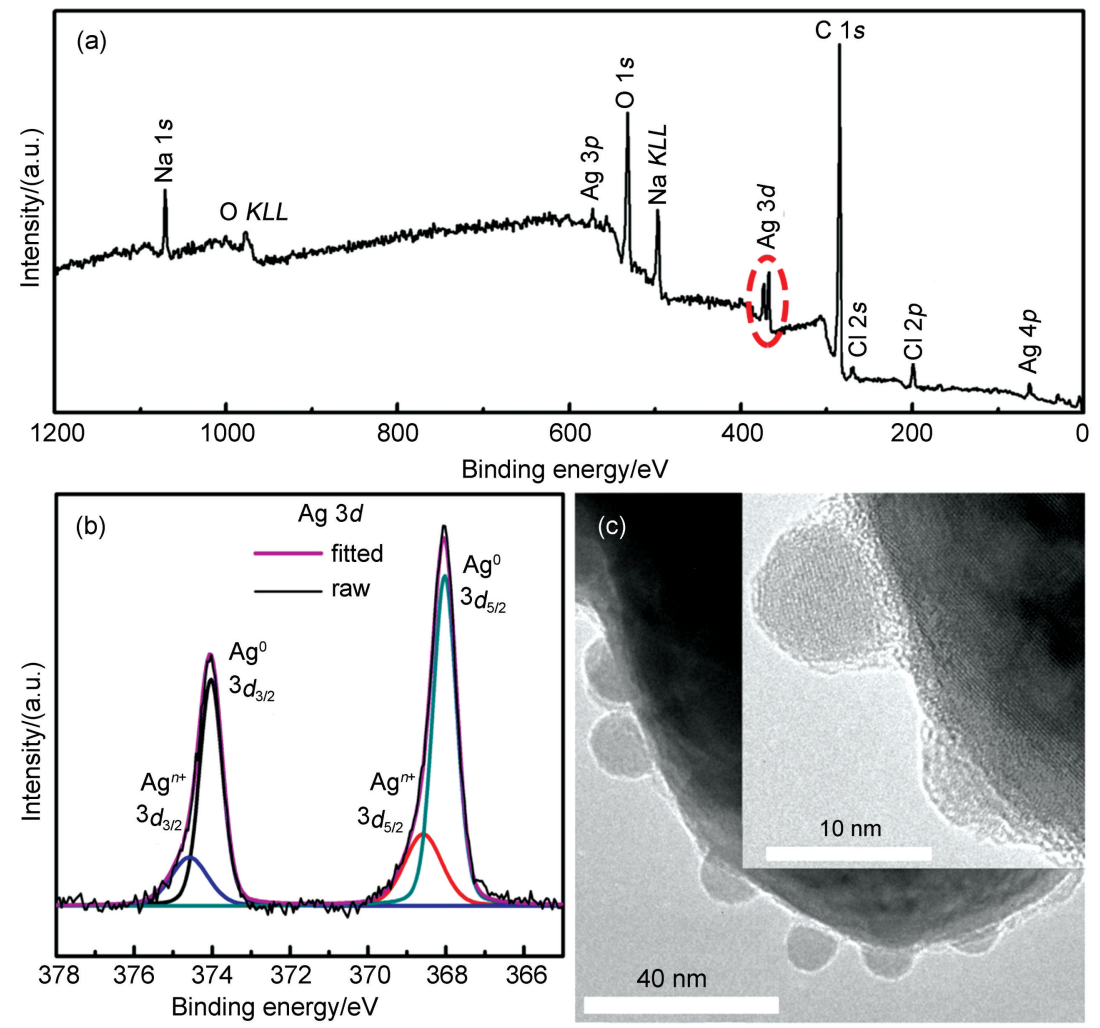

Fig.2 Characterization of $\mathrm{Ag}$ particle from ORC process

(a) XPS wide scan spectra, (b) XPS high-resolution spectra of Ag $3 d$ region, (c) TEM image

ward dehalogenation $^{31}$ and roughed Ag electrode gives significant effect of surface disorder due to high density of defective sites ${ }^{32}$. Therefore, significant increase of surface area and the concentration of defective sites are responsible for the increase of current density and positive shift of onset potential (Fig.1).

\subsection{Dechlorination Mechanism of TeCP over Ag(r) cathode}

\subsubsection{Thermodynamic evaluation of the first ET process} by DFT

Under many circumstances dechlorination process of chloroorganics is bielectronic, and ET of the second electron is generally easier than the first one ${ }^{33-36}$. Thus, electrochemical dechlorination process under these circumstances is controlled by the first ET step (Eq.(4)).

$$
\mathrm{TeCP}+\mathrm{e}^{-} \rightleftharpoons \mathrm{TeCP} \cdot
$$

According to the DFT (B3LYP) calculation result (Table 1), the bond length of $\mathrm{C} 4-\mathrm{Cl}$ is increased sharply when ET is occurred either for free $\mathrm{TeCP}$ (from 0.175 to $0.261 \mathrm{~nm}$ ) or TeCP- $\mathrm{Ag}_{4}$ adduct (from 0.174 to $0.248 \mathrm{~nm}$ ). Only a very slight rise, however, is

Table $1 \mathrm{C}-\mathrm{Cl}$ bond length $(\mathrm{nm})$ of TeCP in the process of ET deduced by DFT

\begin{tabular}{ccccc}
\hline Bond & TeCP free & $\mathrm{TeCP}^{\bullet-}$ free & ${\mathrm{TeCP}-\mathrm{Ag}_{4}}$ & $\mathrm{TeCP}^{\bullet^{-}-\mathrm{Ag}_{4}}$ \\
\hline $\mathrm{C} 3-\mathrm{Cl}$ & 0.175 & 0.178 & 0.174 & 0.177 \\
$\mathrm{C} 4-\mathrm{Cl}$ & 0.175 & 0.261 & 0.174 & 0.248 \\
$\mathrm{C} 5-\mathrm{Cl}$ & 0.175 & 0.178 & 0.174 & 0.178 \\
$\mathrm{C} 6-\mathrm{Cl}$ & 0.177 & 0.181 & 0.176 & 0.180 \\
\hline
\end{tabular}

observed for $\mathrm{C}-\mathrm{Cl}$ bond length of other position. This evidenced increase of $\mathrm{C} 4-\mathrm{Cl}$ bond length strongly suggests that $\mathrm{C} 4-\mathrm{Cl}$ should be broken first and therefore 3,5,6-T was the main product.

The adsorption energy of TeCP is $E_{\text {ad }}\left(\mathrm{TeCP}-\mathrm{Ag}_{4}\right)=E_{\text {TeCP-Ag4 }}-$ $\left(E_{\text {TeCP free }}+E_{\mathrm{Ag} 4}\right)$, where $E_{\text {TeCP-Ag } 4}, E_{\text {TeCP free, }}$, and $E_{\mathrm{Ag} 4}$ are the intrinsic energy of $\mathrm{TeCP}-\mathrm{Ag}_{4}, \mathrm{TeCP}$ free, and $\mathrm{Ag}_{4}$ cluster, respectively. Among electrochemical reaction involves adsorption, especially in which the product was strongly adsorbed, the reaction could be occurred easier compared to diffusion controlled reaction for the adsorption energy of the product can decrease the activation energy of reactant ${ }^{37}$. This feature appears to be well satisfied by the ET process of TeCP, in which the adsorption energy of TeCP ${ }^{\bullet}$ on $\mathrm{Ag}_{4}$ is much stronger $\left(-172.57 \mathrm{~kJ} \cdot \mathrm{mol}^{-1}\right)$ than those for TeCP $\left(-116.99 \mathrm{~kJ} \cdot \mathrm{mol}^{-1}\right)$. This result suggests that the activation energy is decreased by the adsorption energy of the product, evidences that ET process of TeCP can be obviously catalyzed by silver.

Considering the polarization effect, the experimental potentials values are usually more negative compared with corresponding theoretical values. However, in our experiments, the observed reduction potential $\left(E_{\mathrm{p}}=-0.74 \mathrm{~V}\right.$, Fig. 1$)$ is obviously positive than the theoretical value. Perhaps the main reason centers on taking no account of the solvent effect in the process of calculation. Both ET process of $\mathrm{TeCP}$ free and $\mathrm{TeCP}-\mathrm{Ag}_{4}$, however, are not considering the solvent effect, so the value difference of these two processes still can be used as reference. Table 2 reports that the enthalpy and Gibbs free energy change of ET process for TeCP$\mathrm{Ag}_{4}$ are lower than that for free $\mathrm{TeCP}$ but all of them are positive. 
Table 2 Thermodynamic energies and potentials of ET process deduced by DFT

\begin{tabular}{cccc}
\hline \multirow{2}{*}{ ET process } & \multicolumn{2}{c}{ Energy $/\left(\mathrm{kJ} \cdot \mathrm{mol}^{-1}\right)$} & \\
\cline { 2 - 3 } & \multicolumn{1}{c}{$\Delta / \mathrm{V}($ vs $\mathrm{Ag} / \mathrm{AgCl})$} \\
\hline $\mathrm{TeCP}$ free $+\mathrm{e}^{-} \rightarrow \mathrm{TeCP}^{\bullet-}$ free & 150.99 & \multicolumn{1}{c}{$\Delta{ }^{-}$} & \\
$\mathrm{TeCP}-\mathrm{Ag}_{4}+\mathrm{e}^{-} \rightarrow \mathrm{TeCP}^{-}-\mathrm{Ag}_{4}$ & 95.41 & 83.24 & -1.64 \\
\hline
\end{tabular}

In addition, the predicted reduction potential of adsorbed $\mathrm{TeCP}$ is more positive than those of TeCP free. This result implies that ET process cannot be conduct spontaneously and the energy need for the ET process with $\mathrm{Ag}_{4}$ cluster was smaller than that for $\mathrm{TeCP}$ free.

On the whole, DFT calculation suggests that ET to the adsorbed $\mathrm{TeCP}$ with strongly adsorbed radical anion $\left(\mathrm{TeCP}_{\text {ads }}^{\bullet-}\right)$ generated is easier and therefore consistent with the fact that dechlorination reaction can be strongly catalyzed by silver.

\subsubsection{Comprehensive consideration about dechlorination mechanism}

To unravel the exact origin of this strong catalysis by the $\operatorname{Ag}(\mathrm{r})$ electrode, we then carried out two $\mathrm{CV}$ experiments that changed the negative potential limit (Fig.3(a,b)). Two mini reductive peaks can be observed in Fig.3(a), besides the obvious reductive peak at about $-0.75 \mathrm{~V}$ (the product of this latter process is 3,5,6-T; see Entry 1 in Table 3$)$. These mini irreversible peaks are turned into two pairs of redox peaks with $E_{\mathrm{p}}=-0.48 \mathrm{~V} /-0.45 \mathrm{~V}$ and $E_{\mathrm{p}}=$ $-0.58 \mathrm{~V} /-0.53 \mathrm{~V}$ as the negative potential limit changed to -0.70
V (Fig.3(b)). In addition, a small double-layer charging current is presented in the potential range from -0.10 to $-0.40 \mathrm{~V}$, indicating that the adsorption of TeCP was not very strong after $-0.40 \mathrm{~V}$ (Fig.3(b)). It is assumed that, with the potential moves negatively, the electrostatic affinity turns weak and subsequently leads to the partial desorption of TeCP. Therefore, it is likely that the mini redox peaks with $E_{\mathrm{p}}=-0.48 \mathrm{~V} /-0.45 \mathrm{~V}$ are related to desorption/ adsorption of TeCP. Peaks with $E_{\mathrm{p}}=-0.58 \mathrm{~V} /-0.53 \mathrm{~V}$ are generally observed in CV curves involving adsorption or metal underpotential deposition ${ }^{38}$. Therefore, it is highly possible that the mini redox peaks are related to a surface redox process with the product strongly adsorbed ${ }^{37}$.

To assign the redox peaks with $E_{\mathrm{p}}=-0.48 \mathrm{~V} /-0.45 \mathrm{~V}$ and $E_{\mathrm{p}}=$ $-0.58 \mathrm{~V} /-0.53 \mathrm{~V}$ further, in-situ SERS were recorded at different potentials ranging from -0.30 to $-1.10 \mathrm{~V}$ (Fig.3(c)). At potentials of -0.30 and $-0.40 \mathrm{~V}$, the three characteristic bands of TeCP (ring breathing (1005 and $\left.1050 \mathrm{~cm}^{-1}\right), \mathrm{COO}^{-}$symmetric stretching $\left(1386 \mathrm{~cm}^{-1}\right)$ and $\mathrm{C}-\mathrm{C}$ or $\mathrm{C}-\mathrm{N}$ stretching $\left(1478 \mathrm{~cm}^{-1}\right.$ and 1558 $\left.\left.\mathrm{cm}^{-1}\right)\right)^{20-22}$ implies an interaction between TeCP and the silver surface. When the potential is more negative than $-0.70 \mathrm{~V}$, the SERS signal almost disappears. This is because the zero charge potential of silver electrode in neutral $\mathrm{NaClO}_{4}$ aqueous sodium located at $-0.67 \mathrm{~V}$ and TeCP was in the form of anion ${ }^{39}$. SERS signal intensity tested at -0.30 and $-0.40 \mathrm{~V}$ is much higher than those recorded in other potentials. This observation suggests that the reductive peak at $-0.48 \mathrm{~V}$ corresponds to the reversible partial
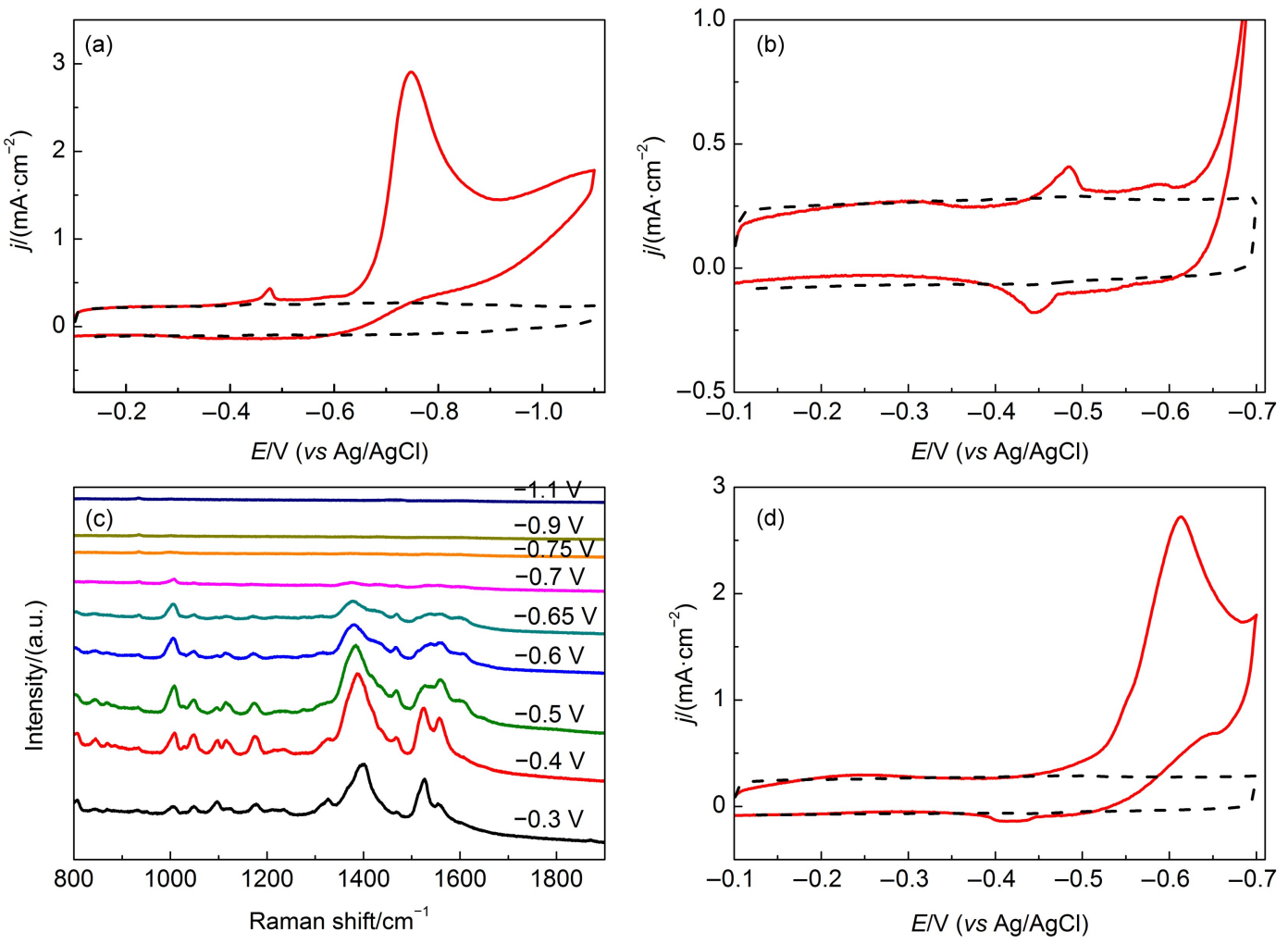

Fig.3 CV curves and SERS spectra of an $\mathrm{Ag}(\mathrm{r})$ electrode in absence/presence of TeCP (a, b) $0.5 \mathrm{~mol} \cdot \mathrm{L}^{-1} \mathrm{NaClO}_{4}+5 \mathrm{mmol} \cdot \mathrm{L}^{-1} \mathrm{TeCP}, \mathrm{pH}=7.0$; (c) $0.5 \mathrm{~mol} \cdot \mathrm{L}^{-1} \mathrm{NaClO}_{4}+20 \mathrm{mmol} \cdot \mathrm{L}^{-1} \mathrm{TeCP}, \mathrm{pH}=7.0$; (d) $0.5 \mathrm{~mol} \cdot \mathrm{L}^{-1} \mathrm{NaClO}_{4}+2.5 \mathrm{mmol} \cdot \mathrm{L}^{-1} \mathrm{HClO}_{4}+5 \mathrm{mmol} \cdot \mathrm{L}^{-1} \mathrm{TeCP}, \mathrm{pH}=4.0 . v=50 \mathrm{mV} \cdot \mathrm{s}^{-1}$ 
Table 3 Electroreductions of TeCP on $\mathrm{Ag}(\mathrm{r})$ electrode at $298 \mathrm{~K}$

\begin{tabular}{|c|c|c|c|c|c|c|c|c|}
\hline \multirow{2}{*}{ Entry } & \multirow{2}{*}{ Operating conditions } & \multirow{2}{*}{$E / \mathrm{V}$} & \multirow{2}{*}{$t / \min$} & \multirow{2}{*}{$\mathrm{pH}$ range } & \multicolumn{4}{|c|}{ Final product distribution/\% } \\
\hline & & & & & $\mathrm{TeCP}$ & $3,5,6-\mathrm{T}$ & $3,6-\mathrm{D}$ & $3,5-\mathrm{D}$ \\
\hline $1^{\mathrm{a}}$ & $5 \mathrm{mmol} \cdot \mathrm{L}^{-1} \mathrm{TeCP}(\mathrm{pH}=7.0)$ & -0.80 & 30 & $7.0-11.5$ & 8.4 & 83.1 & 4.3 & 0.0 \\
\hline $2^{\mathrm{b}}$ & $5 \mathrm{mmol} \cdot \mathrm{L}^{-1} \mathrm{TeCP}(\mathrm{pH}=4.0)$ & -0.55 & 30 & $4.0-2.0$ & 60.0 & 35.0 & 0.0 & 4.3 \\
\hline
\end{tabular}

awith $0.5 \mathrm{~mol} \cdot \mathrm{L}^{-1} \mathrm{NaClO}_{4}$ as anolyte and $0.5 \mathrm{~mol} \cdot \mathrm{L}^{-1} \mathrm{NaClO}_{4}$ as supporting electrolyte of cathode chamber;

${ }^{\text {b with }} 0.5 \mathrm{~mol} \cdot \mathrm{L}^{-1} \mathrm{HClO}_{4}$ as anolyte and $0.5 \mathrm{~mol} \cdot \mathrm{L}^{-1} \mathrm{NaClO}_{4}$ as supporting electrolyte of cathode chamber

desorption of TeCP. When the cathode is held at $-0.50,-0.60$, and $-0.65 \mathrm{~V}$, respectively, the appearance of a new characteristic band $\left(\mathrm{C}-\mathrm{C} \text { stretching, } 1650 \mathrm{~cm}^{-1}\right)^{20-22}$ suggests that the reductive peak at $-0.58 \mathrm{~V}$ corresponds to the reversible injection of an electron on the pyridine ring of $\mathrm{TeCP}$ and the formation of an adsorbed radical anion. This catalytic effect can be proved by DFT result that product of the first ET process of TeCP (Eq.(4)) is strongly adsorbed (more strong than $\mathrm{TeCP}$ ) and both $\mathrm{TeCP}$ and $\mathrm{TeCP}^{\cdot-}$ can be the origin of signal detected by SERS.

In fact, it has been well established that ET to aromatic halides follows a stepwise mechanism. Because they have low lying $\pi^{*}$ orbitals, transient radical anions can formed upon $1 \mathrm{e}^{-}$injection and the cleavage step can be viewed as an intramolecular dissociative $\mathrm{ET}^{10}$. So, it is believed that peaks at $-0.58 \mathrm{~V}$ can be assigned to the reversible process (Eq.(4)) in which electron was initially accommodated on the pyridine ring of adsorbed $\mathrm{TeCP}$, and resulted stable radical anion $\left(\mathrm{TeCP}_{\text {ads }}^{--}\right)$. Therefore, $\mathrm{TeCP}_{\text {ads }}^{--}$is inert with water and the cleavage step induced by intramolecular ET to the $\sigma^{*}$ orbital was completely prohibited. On the whole, SERS spectra recorded at potentials -0.30 and $-0.40 \mathrm{~V}$ show the adsorption of TeCP; decreased adsorption intensity indicates that cathodic peak of $-0.48 \mathrm{~V}$ is assigned to partial desorption of TeCP; new signal at $1650 \mathrm{~cm}^{-1}$ combined with DFT evidence assumes that reductive peak at $-0.58 \mathrm{~V}$ is responsible of a underpotential and reversible ET process.

A CV experiment with the aid of $\mathrm{H}^{+}$was carried out to investigate the protonation of TeCP. As shown in Fig.3(d), the reductive section of the mini redox peaks evolves into a significant irreversible reductive peak (corresponding to the reduction of TeCP to 3,5,6-T, see entry 2 in Table 3 ). It is worth noting that the reduction peak has been justified at $-0.61 \mathrm{~V}$ rather than the former tested $-0.75 \mathrm{~V}$ (Fig.3(a)) after the addition of very little $\mathrm{H}^{+}$to the tested solution. It means that protonation of TeCP occurred easier in the presence of $\mathrm{H}^{+}$. In fact, $\mathrm{H}^{+}$is a stronger proton donor rather than $\mathrm{H}_{2} \mathrm{O}$. Consisted with previous reports by Gennaro group ${ }^{40}$, the result indicates that the electrocatalytic activity of $\mathrm{Ag}(\mathrm{r})$ electrode towards hydrodechlorination of $\mathrm{TeCP}$ can be enhanced by the adding of a stronger proton donor. Therefore, it was likely that dechlorination of $\mathrm{TeCP}$ was a concerted manner in acid aqueous solution.

\section{Conclusions}

The data of voltammetric, DFT calculation, SERS, and electrolysis have provided a preliminary coherent evidence to rationalize the exceptional catalytic properties of $\mathrm{Ag}$ cathodes during the reduction of TeCP. Based on the mechanism, the catalytic property of $\mathrm{Ag}(\mathrm{r})$ electrodes stems from the fact that they involve reduction of $\mathrm{TeCP}$ adsorbed on the silver surface so as to yield directly a strongly adsorbed $\mathrm{TeCP}_{\text {ads }}^{\cdot-}$ and this $\mathrm{TeCP}_{\text {ads }}^{\bullet-}$ can be reduced to $\mathrm{R}^{-}$or decomposed to 3,5,6- $\mathrm{T}$ with the aid of $\mathrm{H}^{+}$in a concerted proton-electron transfer process probably. Such a pathway drastically differs from the outer-sphere electro-reduction at GC electrode, hence, modifies the thermodynamics and kinetics of the first reduction stage. Such important mechanistic changes must be responsible for the important anodic shift of the voltammetric wave at $\mathrm{Ag}$ electrodes.

\section{References}

(1) Isse, A. A.; Durante, C.; Gennaro, A. Electrochem. Commun. 2011, 13, 810. doi: 10.1016/j.elecom.2011.05.009

(2) Yong, B.; Yu, G.; Huang, J. Acta Phys. -Chim. Sin. 2006, 22, 306. [杨 波, 余 刚, 黄 俊. 物理化学学报, 2006, 22, 306.] doi: 10.1016/S1872-1508(06)60006-5

(3) Rondinini, S.; Vertova, A. Electroreduction of Halogenated Organic Compounds. In Electrochemistry for the Environment; Comninellis, C., Chen G. Eds.; Springer: New York, 2010; pp 279-284. doi: 10.1007/978-0-387-68318-8

(4) Sun, Z. R.; Li, B. H.; Hu, X.; Shi, M.; Ge, H.; Peng, Y. Z. J. Chem. Ind. Eng. 2008, 59, 1271. [孙治荣, 李保华, 胡 翔, 石 敏, 葛 慧, 彭永臻, 化工学报, 2008, 59, 1271.] doi: 10.3321/j.issn:0438-1157.2008.05.031

(5) Scialdone, O.; Guarisco, C.; Galia, A.; Herbois, R. J. Electroanal. Chem. 2010, 641, 14. doi: 10.1016/j. jelechem.2010.01.018

(6) Isse, A. A.; Mussini, P. R.; Gennaro, A. J. Phys. Chem. C 2009, 113, 14983. doi: 10.1021/jp904797m

(7) Xu, Y. H.; Ma, H. X.; Cai, Q. Q.; Zhu, Y. H.; Ma, C. A. Acta Phys. -Chim. Sin. 2013, 29, 973. [徐颖华, 马红星, 蔡倩倩, 朱英 红, 马淳安. 物理化学学报, 2013, 29, 973.] doi: 10.3866/PKU. WHXB201302283

(8) Isse, A. A.; Giusti, A. D.; Gennaro, A.; Falciola, L.; Mussini, P. R. Electrochim. Acta 2006, 51, 4956. doi: 10.1016/j. electacta.2006.01.039

(9) Andrieux, C. P.; Gorande, A. L.; Savéant, J. M. J. Am. Chem. Soc. 1992, 114, 6892. doi: 10.1021/ja00043a039

(10) Isse, A. A.; Falciola, L.; Mussini, P. R.; Gennaro, A. Chem. Commun. 2006, No. 3, 344. doi: 10.1039/b513801a

(11) Isse, A. A.; Berzi, G.; Falciola, L.; Rossi, M.; Mussini, P. R.; Gennaro, A. J. Appl. Electrochem. 2009, 39, 2217. doi: 10.1007/ 
s10800-008-9768-Z

(12) Isse, A. A.; Gottardello, S.; Durante, C.; Gennaro, A. Phys. Chem. Chem. Phys. 2008, 10, 2409. doi: 10.1039/b719936h

(13) Rondinini, S.; Aricci, G.; Krpetic, Z.; Locatelli, C.; Minguzzi, A.; Porta, F.; Vertova, A. Fuel Cells 2009, 9, 253. doi: 10.1002/ fuce. 200800083

(14) Ardizzone, S.; Cappelletti, G.; Doubova, L. M.; Mussini, P. R.; Passeri, S. M.; Rondinini, S. Electrochim. Acta 2003, 48, 3789. doi: 10.1016/S0013-4686(03)00512-7

(15) Isse, A. A.; Gottardello, S.; Maccato, C.; Gennaro, A. Electrochem. Commun. 2006, 8, 1707. doi: 10.1016/j. elecom.2006.08.001

(16) Saez, V.; Esclapez, M. D.; Bonete, P.; Gonzalez-Garcia, J.; Perez, J. M. Electrochim. Acta 2008, 53, 3210. doi: 10.1016/j. electacta.2007.11.023

(17) Esclapez, M. D.; Diez-Garcia, M. I.; Saez, V.; Tudela, I.; Perez, J. M.; Gonzalez-Garcia, J.; Bonete, P. Electrochim. Acta 2011, 56, 8138. doi: 10.1016/j.electacta.2011.05.133

(18) Wang, A.; Huang, Y. F.; Sur, U. K.; Wu, D. Y.; Ren, B.; Rondinini, S.; Amatore, C.; Tian, Z. Q. J. Am. Chem. Soc. 2010, 132, 9534. doi: 10.1021/ja1024639

(19) Huang, Y. F.; Wu, D. Y.; Wang, A.; Ren, B.; Rondinini, S.; Tian, Z. Q.; Amatore, C. J. Am. Chem. Soc. 2010, 132, 17199. doi: $10.1021 / \mathrm{ja} 106049 \mathrm{c}$

(20) Sun, S. C.; Bernard, I.; Birke, R. L.; Lombardi, J. R J. Electroanal. Chem. 1985, 196, 359. doi: 10.1016/0022-0728 (85)80033-4

(21) Wen, R.; Fang, Y. Vib. Spectrosc. 2005, 39, 106. doi: 10.1016/j. vibspec.2005.01.001

(22) Dressler, D. H.; Mastai, Y.; Rosenbluh, M.; Fleger, Y. J. Mol. Struct. 2009, 935, 92. doi: 10.1016/j.molstruc.2009.06.042

(23) Xu, Y. H.; Zhang, H.; Chu, C. P.; Ma, C. A. J. Electroanal. Chem. 2012, 664, 39. doi: 10.1016/j.jelechem.2011.10.010

(24) Xu, Y. H.; Zhu, Y. H.; Zhao, F. M.; Ma, C. A. Appl. Catal. A: Gen. 2007, 324, 83. doi: 10.1016/j.apcata.2007.02.049

(25) Xu, Y. H.; Ding, X. F.; Ma, H. X.; Chu, Y. Q.; Ma, C. A. Electrochim. Acta 2015, 151, 284. doi: 10.1016/j. electacta.2014.11.039

(26) Yanai, T.; Tew, D. P.; Handy, N. C. Chem. Phys. Lett. 2004, 393, 51. doi: 10.1016/j.cplett.2004.06.011

(27) Krishnan, R.; Binkley, J. S.; Seeger, R.; Pople, J. A. J. Chem. Phys. 1980, 72, 650. doi: 10.1063/1.438955

(28) McLean, A. D.; Chandler, G. S. J. Chem. Phys. 1980, 72, 5639. doi: $10.1063 / 1.438980$

(29) Frisch, M. J.; Trucks, G. W.; Schlegel, H. B.; et al. Gaussian 03, Revision C.01; Gaussian Inc.: Pittsburgh, PA, 2003.

(30) Lopez-Salido, I.; Lim, D. C.; Kim, Y. D. Surf. Sci. 2005, 588, 6. doi: 10.1016/j.susc.2005.05.021

(31) Minguzzi, A.; Lugaresi, O.; Aricci, G.; Rondinini, S.; Vertova, A. Electrochem. Commun. 2012, 22, 25. doi: 10.1016/j. elecom.2012.05.014

(32) Lugaresi, O.; Perales-Rondón, J. V.; Minguzzi, A.; Solla-Gullón, J.; Rondinini, S.; Feliu, J. M.; Sánchez-Sánchez, C. M. Appl. Catal. B: Environ. 2015, 163, 554. doi: 10.1016/j. apcatb.2014.08.030

(33) Cardinale, A.; Isse, A. A.; Gennaro, A.; Robert, M.; Savéant, J. M. J. Am. Chem. Soc. 2002, 124, 13533. doi: 10.1021/ja0275212

(34) Isse, A. A.; Gennaro, A. J. Phys. Chem. A 2004, 108, 4180. doi: $10.1021 / j p 036782 \mathrm{a}$

(35) Savéant, J. M. Chem. Rev. 2008, 108, 2348. doi: 10.1021/ cr068079z

(36) Costentin, C.; Louault, C.; Robert, M.; Teillout, A. L. J. Phys. Chem. A 2005, 109, 2984. doi: 10.1021/jp0442549

(37) Bard, A. J.; Faulkner, L. R. Electrochemical Methods: Fundamentals and Applications, 2nd ed.; Wiley: New York, 2001; pp 595-601.

(38) Ma, C. A.; Ma, H.; Xu, Y. H.; Chu, Y. Q.; Zhao, F. M. Electrochem. Commun. 2009, 11, 2133. doi: 10.1016/j. elecom.2009.09.013

(39) Bode, D. D.; Andersen, J. T. N.; Eyring, H. J. Phys. Chem. 1967, 71, 792. doi: 10.1021/j100863a002

(40) Durante, C.; Isse, A. A.; Sandonà, G.; Gennaro, A. Appl. Catal. B: Environ. 2009, 88, 479. doi: 10.1016/j.apcatb.2008.10.010 